\title{
Donat Jerzy Mierzejewski, Bezpieczeństwo europejskie w warun- kach globalizacyjnych, Wydawnictwo Adam Marszalek, Toruń 2011, ss. 262.
}

Zagadnienie bezpieczeństwa europejskiego jest problemem bardzo złożonym i doczekało się licznych opracowań naukowych ujmujących je z perspektywy różnych dyscyplin, takich jak politologia, stosunki międzynarodowe, ekonomia, co zaowocowało mnogością podejść badawczych, niezliczoną liczbą definicji, modeli i typologii. Dodatkowo we współczesnym, ulegającym ciaggłym zmianom, coraz mniej przewidywalnym świecie, Europa musi mierzyć się $\mathrm{z}$ problemami związanymi $\mathrm{z}$ nowymi zagrożeniami. Wszystko to czyni temat bezpieczeństwa aktualnym, a recept i odpowiedzi na te wyzwania stara się dostarczać literatura.

W obliczu takiej wielowątkowości materii Donatowi Jerzemu Mierzejewskiemu udaje się znaleźć niszę, w obrębie której porządkuje pewne aspekty złożonego problemu, jakim jest bezpieczeństwo europejskie. Zasadniczy problem podjęty w pracy Donata Jerzego Mierzejewskiego zawiera się bowiem w pytaniu badawczym o wpływ procesów globalizacyjnych na bezpieczeństwo europejskie. A gówna hipoteza zostaje przez Autora sformułowana w następujący sposób: procesy globalizacyjne są pochodną przemian politycznych, cywilizacyjnych, ekonomicznych i postępu technicznego, czynią jednostki i zbiorowości ludzkie oraz podmioty międzynarodowe wzajemnie od siebie zależnymi, kreują procesy polityczne w skali narodowej i międzynarodowej, wyzwalają potrzebę integracji, generują zagrożenia o charakterze globalnym, mają więc wpływ na kształtowanie się potrzeby wspólnego bezpieczeństwa, tworzenie jego struktur oraz determinację wspólnego działania w tym zakresie.

Zaletą pracy jest układ o charakterze chronologiczno-problemowym, w ten sposób Autor daje czytelnikowi wgląd w genezę i przebieg podejmowanych wątków problemu. Pozwala zaprezentować kwestie bezpieczeństwa i genezę globalizacji jako procesu. Poszczególne obszary badawcze interesujące Autora, znajdują odzwierciedlenie w kolejnych rozdziałach pozycji. Zakres chronologiczny pracy obejmuje okres od zakończenia II wojny światowej po czasy bieżące, ze szczególnym skupieniem na analizie procesów, jakie następują po rozpadzie układu dwubiegunowego w stosunkach międzynarodowych.

We Wstępie do swojej pracy Autor umieszcza wszystkie ważne dla dalszych rozważań elementy, są tu więc uwagi terminologiczne kluczowe dla podejmowanego zagadnienia, postawienie hipotezy głównej i zaprezentowanie szczególowych pytań badawczych wraz z odpowiadającymi im roboczymi hipotezami. Po tak dopracowanym wstępie czytelnik mógłby oczekiwać klarownego podsumowania, będącego zebraniem wniosków po zweryfikowaniu hipotez, niestety Zakończenie nie do końca spełnia tę funkcję, część wniosków pozostaje rozsiana w toku rozważań.

Pierwszy obszar dotyczy wyzwań dla współczesnej Europy i stanowi analizę oraz syntezę przemian, jakie zaszły w rozwoju bezpieczeństwa europejskiego po II wojnie światowej, a które są konsekwencją procesów globalizacyjnych. Omówiony został tu przebieg procesów globalizacyjnych i ich następstwa we współczesnym świecie, dotyczące zwłaszcza istoty państwa demokratycznego, społeczeństwa, polityki wewnętrznej i zagranicznej. Autor zwraca w tym miejscu uwagę na wpływ na bezpieczeństwo takich elementów jak wielokulturowość współczesnych społeczeństw czy rola korporacji medialnych w kreowaniu polityki międzynarodowej. Łączy te zagadnienia z takimi zjawiskami jak suwerenność i deterytorializacja. Omawiając kwestie zależności między bezpieczeństwem międzynarodowym a suwerennością państw, uwzględnia również taki czynnik jak przenoszenie centrów władzy z obszarów polityki do sfery ekonomii. Spora część omawianej książki obejmuje problematykę instytucjonalizacji procesu bezpieczeństwa europejskiego. Autor dokonuje tu próby oceny bezpieczeństwa międzynarodowego na przełomie wieków oraz analizy działalności ONZ, OBWE, NATO, WNP i UE w kreowaniu polityki bezpieczeństwa. 
W części poświęconej terroryzmowi Autor dokonuje koniecznych z punktu widzenia tematyki tej części pracy wyjaśnień dotyczących źródeł, nurtów i form terroryzmu. Kreśli prognozy rozwoju w warunkach globalizacji takich zjawisk jak terroryzm i superterroryzm. Obszernie omawia międzynarodowe unormowania prawne oraz możliwości zapobiegania i reagowania na akty terroryzmu w skali globalnej i europejskiej, a także zakres międzynarodowych uregulowań prawnych w zakresie zwalczania ataków $\mathrm{z}$ wykorzystaniem przez terrorystów broni masowego rażenia.

Problematyka strategii bezpieczeństwa stanowi kolejny obszar badawczy, którym zajmuje się D. J. Mierzejewski i skoncentrowana jest na charakterystyce koncepcji rozwoju bezpieczeństwa światowego w aspekcie globalizacji do roku 2015. Analizie poddany zostaje dokument z 2000 r: Raport CIA pt. Globalne kierunki 2015. Dialog o przyszlości z pozarzadowymi specjalistami wraz z czterema scenariuszami przewidywanego kształtowania się światowej sytuacji w okresie do 2015 roku. Ponadto czytelnik odnajdzie tu omówienie Strategii bezpieczeństwa narodowego Stanów Zjednoczonych Ameryki, Strategii bezpieczeństwa narodowego i Doktryny wojennej Federacji Rosyjskiej, a także Europejskiej strategii bezpieczeństwa oraz Koncepcji strategicznej obrony i bezpieczeństwa czlonków Organizacji Traktatu Pólnocnoatlantyckiego. Pewien niedosyt w pozycji omawiającej bezpieczeństwo europejskie w kontekście przemian globalizacyjnych pozostawia brak odniesienia do deklaracji i koncepcji w zakresie bezpieczeństwa formułowanych chociażby przez Chiny czy Indie, do których prawdopodobnie będzie należała przyszłość świata XXI wieku.

Ostatnią część Autor poświęca na scharakteryzowanie czynników, które mają wpływ na architekturę bezpieczeństwa międzynarodowego, tj. procesy gospodarcze (np. kwestia surowców energetycznych, przesuwanie się ośrodka rozwoju gospodarczego z obszaru atlantyckiego na obszar Pacyfiku czy chociażby następstwa transformacji gospodarczej w państwach postkomunistycznych); jak również migracje, ruchy emancypacyjne i narodowe oraz proliferacja broni masowego rażenia. Wnikliwie zaprezentowane zostały wojskowe aspekty bezpieczeństwa dotyczące głównie kwestii rozbrojeniowych i kontroli działalności wojskowej państw. Rozważaniom tym towarzyszy charakterystyka współczesnych koncepcji bezpieczeństwa europejskiego m.in. koncepcji bezpieczeństwa wspólnego zabezpieczania się przed agresją w ramach ogólnoeuropejskiego modelu bezpieczeństwa zbiorowego (OBWE); bezpieczeństwo w ramach kooperatywnej (NATO), koncepcji bezpieczeństwa w ramach integrującej się Europy (UE); koncepcji bezpieczeństwa opartej na relacjach między mocarstwami, kształtującymi architekturę bezpieczeństwa zgodnie z własnymi interesami.

Zasługę Autora i spory walor pracy stanowi podanie w skondensowanej formie treści na temat przebiegu zimnej wojny, a także polityki w zakresie bezpieczeństwa do 1991 roku oraz uporządkowanie wielu definicji z dziedziny bezpieczeństwa i klasyfikacji zjawisk z tego zakresu. Wraz z książką Donata Jerzego Mierzejewskiego Bezpieczeństwo europejskie w warunkach globalizacyjnych dostajemy do rąk lekturę, która wpisuje się do grupy publikacji rzetelnie omawiających problematykę bezpieczeństwa europejskiego i jako taka z pewnością posłuży adeptom politologii, stosunków międzynarodowych czy bezpieczeństwa narodowego w przyswajaniu, a nade wszystko porządkowaniu wiedzy. 